\title{
Seasonal trends in air temperature and precipitation in IPCC AR4 GCM output for Kansas, USA: evaluation and implications
}

\author{
N. A. Brunsell,* A. R. Jones, T. L. Jackson and J. J. Feddema \\ Department of Geography, University of Kansas, Lawrence KS 66044, USA
}

\begin{abstract}
Understanding the impacts of future climate change in Kansas is important for agricultural and other socioeconomic sectors in the region. To quantify these impacts, seasonal trends in air temperature and precipitation patterns from decadally averaged monthly output of 21 global climate models under the Special Report on Emissions Scenarios A1B scenario used in the Intergovernmental Panel of Climate Change Assessment Report 4 are examined for six grid cells representing Kansas. To ascertain the performance of the models, we compared model output to kriged meteorological data from stations in the Global Historical Climate Network for the period from 1950 to 2000. Agreement between multimodel ensemble mean output and observations is very good for temperature $\left(r^{2}\right.$ all more than 0.99 , root mean square errors range from 0.84 to $1.48^{\circ} \mathrm{C}$ ) and good for precipitation $\left(r^{2}\right.$ ranging between 0.64 and 0.89 , root mean square errors range from 322 to $1144 \mathrm{~mm}$ ). Seasonal trends for the second half of the 20th century are generally not observed except in modelled temperature trends. Linear trends for the 21 st century are significant for all seasons in all grid cells for temperature and many for precipitation. Results indicate that temperatures are likely to warm in all seasons, with the largest trends being on the order of $0.04{ }^{\circ} \mathrm{C}$ year in summer and fall. Precipitation is likely to increase slightly in winter and decrease in summer and fall. These changes have profound implications for both natural ecosystems and agricultural land uses in the region. Copyright (c) 2009 Royal Meteorological Society
\end{abstract}

KEY WORDS regional climate; grasslands; precipitation; temperature

Received 18 July 2008; Revised 14 April 2009; Accepted 18 April 2009

\section{Introduction}

The central plains region of the United States is one of the largest agricultural producing areas where food production has significant implications to the global economy and food security. This was recognised during the MINK study (Easterling et al., 1993). Therefore, understanding the potential ramifications of climate change in the region is vitally important for understanding future global food and possibly fuel security. Understanding potential future impacts of greenhouse gas (GHG) emissions on the climate of the mid-western United States is critical to understanding how climate change will affect the United States in terms of its food production and agricultural economy (Easterling et al., 1993; US Global Change Research Program USGCRP, 2001; USGCRP forthcoming, 2009). At the same time, the atmospheric dynamics that regulate the climate over the Midwest are such that they make this one of the most difficult areas in the world for assessing potential climate impacts.

This article will set out to assess how climate model projections based on GHG emission scenarios will affect

\footnotetext{
* Correspondence to: N. A. Brunsell, Department of Geography, 1475 Jayhawk Blvd., Lindley Hall 417, Lawrence KS 66045-7613, USA. E-mail: brunsell@ku.edu
}

temperature and precipitation conditions across the Midwest precipitation gradient found, primarily focusing on an area encompassing the state of Kansas. The Intergovernmental Panel on Climate Change (IPCC, 2007) projects that subtropical regions are likely to be most affected by GHG emissions, with significant negative climate outcomes likely to reach into the Midwest of the United States. To assess climate change over the region, we will compare climatologies for the last 50 years against historical global climate model (GCM) simulations to assess how the models simulate the climate of the last 50 years. Following on this assessment, we will assess potential outcomes of future GCM climate change projections for the IPCC Special Report on Emissions Scenarios (SRES) A1B scenario. The SRES A1B scenario assumes that in the near term, emissions will continue to increase, but that by mid century, reductions will take place; thus, it represents an intermediate emissions path into the future (IPCC, 2000).

While we will make an assessment of climate impacts as simulated by GCMs, we also recognise that assessing the impacts of future climate change on agriculture is problematic. Such an assessment must not only consider the impact of climate on crop production but it must also consider additional human drivers, such as cropping choices and world demand for food (Olesen and Bindi, 
2002; Howden et al., 2007). It must also recognise that, in their current state, GCMs do not simulate all possible human-climate interactions. For example, certain land use characteristics (e.g. irrigation, fire management and fertiliser use) or in many of the models observed land use change that affect local and global biophysical and biogeochemical processes (e.g. Claussen et al., 2001) are not included in the global simulations. Yet there is evidence that these land use changes have a significant impact on climate and ecological processes in the Midwest (Bonan, 1999; Changnon et al., 2002; Mahmood et al., 2004).

\section{Background}

The grass lands of the Midwest are one of a number of global grassland ecosystems that occur as a plant adaptation to a high-variable climate conditions. Globally, grassland ecosystems comprise approximately $40 \%$ of the total land surface (Samson and Knopf, 1994), and account for most of the world's agricultural production. These ecosystems are particularly important for regulating biosphere-atmosphere interactions with respect to the transport of energy and mass in both natural and agricultural landscapes (Easterling et al., 1993; USGCRP, 2001). In addition, they are vital to the global food economy, and their societal importance may further increase as the discussion regarding biofuels for fuel production continues in the future (USGCRP, 2001). Therefore, understanding the impacts of global climate change on these regions is vitally important for food security and to improve our ability to adapt to new conditions.

Characterising and understanding the climate of the Midwest have been a much discussed topic beginning with the earliest climate classification systems. The original Köppen classification drew its boundaries based on the vegetation maps of de Candole (Köppen, 1900; Carter and Mather, 1966). The decision to draw climatic boundaries based on vegetation maps led to a number of problems when characterising the climate over the region encompassing a region like Kansas. For example, shallow soils over the Flint Hills region reduce the ability of vegetation to endure drought conditions (e.g. Park et al., 2005). Thus, the forest-grassland ecotone is shifted eastward compared with locations with a similar temperature and precipitation statistics but deeper soils. Such complexities contributed to multiple attempts to redraw the boundaries of the Köppen classification system (e.g. Trewartha and Horn, 1980). Thornthwaite devised his climate classification systems (while at the University of Oklahoma) specifically to avoid determining boundaries on ecotones, but his and follow up systems still are unable to incorporate the problems of the soil boundary conditions (Thornthwaite, 1943, 1948; Feddema et al., 2005). To truly understand the future impacts of climate change on the region, researchers need to integrate not only changes in the drivers of climate change but also how local conditions, such as soils and local climate feedbacks associated with human land cover change, can exacerbate or compensate for some of the impacts.
While early researchers such as Köppen and Thorntwaite mapped climates based on average statistics, they also recognised that these boundaries are dynamic and that the annual range and interannual climate variability a characteristic of grassland. This large natural interannual climate variability contributes to the difficulty of detecting and projecting climate change impacts on these regions. Although the relatively short droughts in the 1910s, the 'Dust Bowl' in the 1930s and the 1950s in the American Midwest, form a strong social image of climate impacts in the Midwest, longer observation periods (10-30 year averages) show that the climate has been relatively stable for most of the 20th century (e.g. Skaggs, 1978). Skaggs (1978) used different time averages of the Palmer Drought Severity Index (Palmer, 1965) to illustrate that for different averaging periods, there was no significant climate trend in the first 75 years of the 20th century. Grundstein (2009) shows a general warming and moistening of the eastern United States, with a gradual shift in the zero moisture index line (where potetnial evapotranspiration equals precipitation) to the west. This is further supported by evidence of a significant wet period in the last quarter of the 20th century (Garbrecht and Rossel, 2002; Garbrecht et al., 2004). However, this wet period from about 1980 to 2000 shows some evidence of declining in the southern parts of the Midwest in the first decade of the 21st century (Garbrecht et al., 2004). In terms of temperatures, a number of studies suggest that temperatures have been warming in the region (USGCRP, 2001; IPCC, 2007; Patterson, 2008). Robeson (2004) demonstrates that much of the change in temperature has been linked to increases in the winter time daily minimum temperatures. This is further supported in global trends of annual decreases in the number of cold nights and a commensurate increase in the number of annual warm nights (Alexander et al., 2006).

In aggregate, most assessments of Midwest climate change point to an accelerated warming in the last few decades accompanied by an increase in precipitation (e.g. Grundstein, 2008). However, it is also clear that the climate of the Midwest has seen much larger climate anomalies prior to the instrumental record. Tree ring evidence suggests more extensive and intense drought episodes (Woodhouse and Overpeck, 1998). At the same time, other evidence suggests not only the potential for severe droughts but also significant shifts in wind patterns, as observed from sand dune orientation patterns in the Sand Hills region of Nebraska (Venkatatamana et al., 2006). These studies raise the question of what mechanism might have been responsible for such past climate change and whether such changes might be possible in the future or if they could be triggered by anthropogenic GHG-forcing scenarios. Observations show that anomalous sea surface temperatures in both the North Atlantic and Pacific Ocean could trigger such events (McCabe et al., 2004). GCM experiments support this hypothesis, with the most intense drought simulated with forced SST anomalies in both locations simultaneously (Feng et al., 2008). However, Feng et al. 
(2008) were not able to replicate the observed wind patterns associate with the historical events, suggesting this may not be a definitive explanation of the observed historical drought events.

Other recent work points to specific weather anomalies that could explain some of the high interannual climate variability observed over the region. Persistent drought over Mexico, extending into the southwestern United States in the beginning of the 21st century, has possible links to anthropogenic warming associated with GHG emissions and a consequent weakening of the Hadley Circulation (Stahle et al., 2009). At the same time, severe flooding in 1993 and 2008 to the north of the study area has been linked to the 'Maya Express' a mechanism by which moisture from the Gulf of Mexico near the Yucatan Peninsula is transported northward as a result of a persistent weather pattern (Dirmeyer and Kinter, 2009). Although it is not clear whether these later mechanisms can be simulated in a GCM, we propose to assess how GCMs simulate future decadal scale temperature and precipitation patterns over the region. Perhaps these conflicting trends are an indication of increased climate variability as is projected in the IPCC fourth assessment report (AR4) (IPCC, 2007).

Assessments of future climate change based on the multimodel IPCC AR4 approach suggest that near surface air temperature in the central United States will likely warm on the order of $4{ }^{\circ} \mathrm{C}$ for the SRES A1B scenario (IPCC, 2007). Consequences of increases in minimum air temperature potentially may lead to decreases in productivity of the $\mathrm{C}_{4}$ grasses and crops as well as increased productivity by $\mathrm{C}_{3}$ forbs (Alward et al., 1999). The distinction between $\mathrm{C}_{3}$ and $\mathrm{C}_{4}$ photosynthesis pathways relates to the ability to close the stomata during warmer periods of the day and therefore $\mathrm{C}_{4}$ generally being better at conserving water. In agricultural regions, such as Kansas, this is significant for grazing and fodder for meat production. Another potential implication of climate change is longer growing seasons. While this may seem beneficial for agricultural production, this is not always the case. Longer growing seasons may not result in increased $\mathrm{CO}_{2}$ assimilation if water becomes a limiting factor (Sacks et al., 2007).

Different grassland ecosystems respond differently to climate change, particularly in response to water availability via soil moisture (Frank and Inouye, 1994). The role of water limitation on vegetation responses varies across grassland ecosystems at relatively small spatial scales (hundreds of kilometers). In the Great Plains region, for example, limited water availability in the eastern portions of the grasslands may indicate that $\mathrm{C}_{4}$ species will become more abundant (Knapp et al., 2001).

In addition to altering the species composition in natural grasslands, a change in the regional precipitation regime has implications for agriculture. Through the Clausius-Clapeyron relationship, due to the strong temperature dependence of saturation vapour pressure, slight increases in precipitation could still result in effectively drier conditions. Warmer, drier conditions will affect the economic viability of agricultural production (via crop selection) and will necessitate effective adaptation mechanisms such as increasingly more efficient irrigation technology and/or new crop varieties.

In terms of productivity, grassland ecosystems are the most sensitive to rainfall variability (Knapp and Smith, 2001). Productivity of $\mathrm{C}_{4}$ grasslands is known to be sensitive to the frequency of precipitation events largely through a modulation of the soil moisture under both rainfall manipulation studies (Fay et al., 2003) and natural conditions (Nippert et al., 2006).

One important component of understanding the impact of climate change on grasslands is to understand the importance of feedback cycles between the biotic and climate systems. The role of soil moisture-precipitation feedbacks has been shown to vary spatially (Koster et al., 2004; Brunsell, 2006). Through a modelling study, Jones and Brunsell (2009b) show the existence of a positive soil moisture-precipitation feedback in Kansas via an energy balance partitioning (evaporation versus sensible heat flux) mechanism. This implies that any biological control over trends in soil moisture within this region may be amplified by shifts in precipitation. A related mechanism, particularly within the western regions of the state is the role of irrigation. Irrigation is known to affect both the local carbon assimilation (Volk et al., 2000), but it also affects atmospheric boundary layer dynamics such as cloud formation (Marotz et al., 1975), surface energy fluxes (Adegoke et al., 2003, 2007), near surface air temperatures (Mahmood et al., 2004) and precipitation (Segal et al., 1998).

Compounding the effects of air temperature and water use impacts under global warming scenarios is the biological control exhibited by vegetation. It is generally proposed that there is a positive feedback between climatic warming and biospheric processes (Luo, 2007). The role of the biosphere has been shown to have a positive feedback between global warming and the carbon cycle in a coupled carbon-climate model (Cox et al., 2000). In addition to the impacts on air temperature, there are biological implications for the hydrological cycle. Under enriched $\mathrm{CO}_{2}$ conditions, grasslands appear to conserve soil moisture through a reduction in the stomatal conductance and reduced transpiration (Volk et al., 2000). Thus, assessing the response of grassland ecosystems to climate change necessitates understanding of precipitation and temperature impacts in addition to the effect of increased $\mathrm{CO}_{2}$ conditions.

More generally, land use/land cover modifications have a large potential to either exacerbate or alleviate the effects of global climate change through microscale impacts on water and energy cycling. These impacts are not clearly understood due to many feedbacks as well as how to accurately parameterise land use at GCM resolutions (Feddema et al., 2005a, 2005b). To further complicate the issue, the underlying human decision-making processes that control land cover are not well understood at this point (Heistermann et al., 2006). To accurately 
assess mitigation and socio-economic implications of climate change, it is essential that these processes are included in the analysis; particularly in agricultural lands (Olesen and Bindi, 2002; Hopkins and del Prado, 2007; Howden et al., 2007).

Thus, it is important for a number of reasons that we understand the implications of climate change within the state of Kansas and the U.S. Central Plains in general. Therefore, the questions to be addressed in this research are (1) what are the seasonal trends in air temperature and precipitation observed during the second half of the 20th century and how do these match the IPCC AR4 simulations? (2) What are the future trends and implications of climate change for the state of Kansas in the 21 st century?

\section{Methods}

GCM output air temperature and precipitation for decadally averaged monthly values were obtained from 21 models used in the IPCC AR4 IPCC, 2007 (multimodel data obtained from the National Center for Atmospheric Research - also available from Program for Climate Model Diagnosis and Intercomparison). A listing of the models used is given in Table I. The spatial resolution of the models used in this analysis varied (IPCC, 2007: Chapter 11), but for this study, all model results were interpolated to the identical T42 GCM grid resolution. All models were run using the SRES A1B scenario.

Rather than establish which models perform particularly well or poorly in this region, we focus on the intermodel variability and the multimodel ensemble mean to assess the seasonal impacts of climate change in the region. In many cases, the use of the multimodel ensemble has been shown to outperform individual models (for a review, see Tebaldi and Knutti, 2007).

The multimodel ensemble means are calculated using decadally averaged monthly mean air temperature and total precipitation. Six grid cells cover the state of Kansas and are used in this analysis (Figure 1). We use linear regression techniques on seasonally averaged temperature and total precipitation model output to test for trends.

To evaluate the seasonal trends in the GCM output for the region, we compare the trends to meteorological station data from the Global Historical Climate Network (GHCN; Peterson and Vose, 1997; Peterson et al., 1998). While we acknowledge that many of these stations may be either located in less than ideal locations (Pielke et al., 2007) or may exhibit microscale climatic influences that are not representative of the region in general (Pielke et al., 2002), our hope is that by using enough stations a realistic understanding of the regional climatic conditions is achieved. Therefore, a total of 337 stations are used for evaluation (Figure 1).

Table I. List of the global climate models used in this analysis.

\begin{tabular}{|c|c|c|c|}
\hline Number & Group & Name & Country \\
\hline 1 & Canadian Centre for Climate Modelling \& Analysis (T47) & CGCM3.1(T47) & Canada \\
\hline 2 & Canadian Centre for Climate Modelling \& Analysis (T63) & CGCM3.1(T63) & Canada \\
\hline 3 & National Center for Atmospheric Research (CCSM) & CCSM3 & US \\
\hline 4 & Météo-France/Centre National de Recherches Météorologiques & CNRM-CM3 & France \\
\hline 5 & CSIRO Atmospheric Research & CSIRO-Mk3.0 & Australia \\
\hline 6 & $\begin{array}{l}\text { US Department of Commerce/NOAA/Geophysical Fluid Dynamics } \\
\text { Laboratory }\end{array}$ & GFDL-CM2.0 & US \\
\hline 7 & $\begin{array}{l}\text { US Department of Commerce/NOAA/Geophysical Fluid Dynamics } \\
\text { Laboratory }\end{array}$ & GFDL-CM2.1 & US \\
\hline 8 & NASA/Goddard Institute for Space Studies & GISS-AOM & US \\
\hline 9 & NASA/Goddard Institute for Space Studies & GISS-EH & US \\
\hline 10 & NASA/Goddard Institute for Space Studies & GISS-ER & US \\
\hline 11 & LASG/Institute of Atmospheric Physics & FGOALS-g1.0 & China \\
\hline 12 & Institute for Numerical Mathematics & INM-CM3.0 & Russia \\
\hline 13 & Institut Pierre Simon Laplace & IPSL-CM4 & France \\
\hline 14 & $\begin{array}{l}\text { Center for Climate System Research (The University of Tokyo), National } \\
\text { Institute for Environmental Studies, and Frontier Research Center for } \\
\text { Global Change (JAMSTEC) }\end{array}$ & MIROC3.2(hires) & Japan \\
\hline 15 & $\begin{array}{l}\text { Center for Climate System Research (The University of Tokyo), National } \\
\text { Institute for Environmental Studies, and Frontier Research Center for } \\
\text { Global Change (JAMSTEC) }\end{array}$ & MIROC3.2(medres) & Japan \\
\hline 16 & $\begin{array}{l}\text { Meteorological Institute of the University of Bonn, Meteorological } \\
\text { Research Institute of KMA, and Model and Data group. }\end{array}$ & ECHO-G & Germany/Korea \\
\hline 17 & Max Planck Institute for Meteorology & ECHAM5/MPI-OM & Germany \\
\hline 18 & Meteorological Research Institute & MRI-CGCM2.3.2 & Japan \\
\hline 19 & National Center for Atmospheric Research & PCM & US \\
\hline 20 & Hadley Centre for Climate Prediction and Research/Met Office & UKMO-HadCM3 & UK \\
\hline 21 & Hadley Centre for Climate Prediction and Research/Met Office & UKMO-HadGEM1 & UK \\
\hline
\end{tabular}




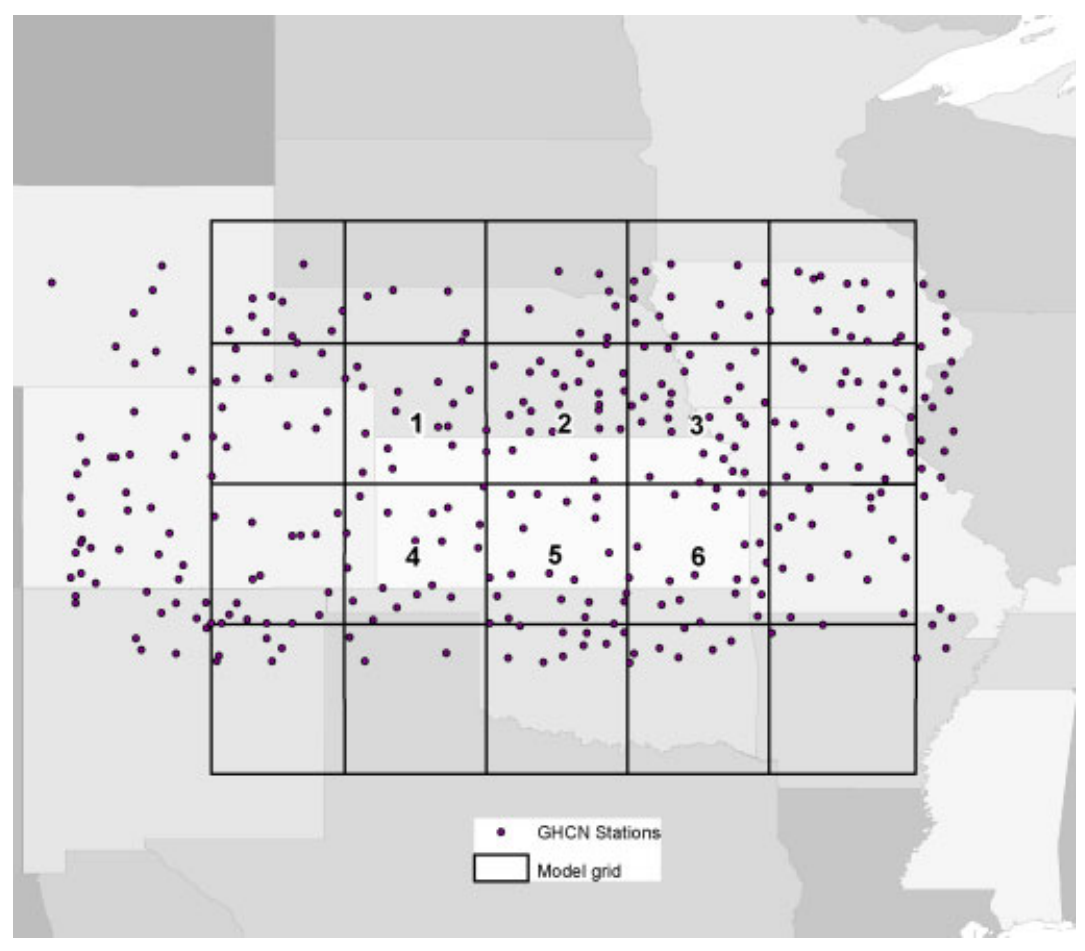

Figure 1. Depiction of global climate model grid cells and Global Historical Climate Network station locations used in this analysis. This figure is available in colour online at www.interscience.wiley.com/ijoc

Rather than compare an individual station or a group of stations with the model output, we interpolated the monthly mean air temperature and total precipitation GHCN data to the grid resolution of the GCM models using kriging (Figure 1). These monthly interpolated values were averaged for each decade to compare with the GCM output using mean absolute differences $(|\mathrm{GHCN}-\mathrm{GCM}|)$. Seasonal and overall trends were evaluated using linear regression on the decadally averaged monthly temperature and precipitation values.

\section{Results}

\subsection{Comparison of observations and model results}

There is large variability between the various models over the region, particularly with respect to summer precipitation (Figure 2). However, when using the ensemble average, the agreement with interpolated station data is quite good (Figure 3). Table II shows the slope, $r^{2}$ and root mean square error (RMSE) values for the agreement between the kriged station data and the ensemble mean GCM output for both monthly precipitation and air temperature. For temperature, the RMSE ranges from 0.84 to $1.48^{\circ} \mathrm{C}$, with all $r^{2}$ being 0.99 or higher. The slopes for temperature are also quite close to the optimal value of 1 . The values for precipitation are more variable, with $r^{2}$ ranging from 0.72 to 0.89 , corresponding to RMSE ranging approximately between 322 and $1144 \mathrm{~mm}$, with slopes range between 0.52 and 1.16 .

The distribution of seasonal precipitation mean absolute differences for each grid cell between the GHCN data and GCM output $(|\mathrm{GHCN}-\mathrm{GCM}|)$ is shown in Figure 4. The largest absolute differences occur during the high precipitation seasons (spring and summer), with summer having the greatest variability in model estimates. Mean spring differences are about $80 \mathrm{~mm}$, while summer demonstrates a slight spatial trend with mean absolute differences decreasing from west (cells 1 and 4) to east (cells 3 and 6). The mean annual rainfall for Kansas is approximately $700 \mathrm{~mm}$, thus this difference represents approximately $10 \%$ of the annual total. This spatial trend is reversed in fall and winter where the difference increases from the western cells (1 and 4) to those covering eastern Kansas (3 and 6). Differences in the fall generally lie between 40 and $60 \mathrm{~mm}$, while the winter differences are on the order of 20 to $40 \mathrm{~mm}$.

The mean absolute differences for seasonal temperatures are shown in Figure 5. All grid cells generally experience between 1 and $2^{\circ} \mathrm{C}$ for each season. Unlike the precipitation differences, there is no clear spatial trend in the differences from west to east.

The intermodel distributions of linear trends in seasonal precipitation for 1950-2000 are shown in Figure 6 for each grid cell. There is a large variance in each cell, for each season. In general, the mean slope is near zero and typically agrees with observed trends (shown as triangles). The ensemble mean slopes and associated $r^{2}$ values are shown in Table III. None of the values are statistically significant at the $p<0.05$ level. The slopes derived from the GHCN data contain four values that are significant: an increase in winter and spring precipitation at points 5 and 6 (Table III). The $r^{2}$ values are low (on the order of 0.1 ), but the slopes are significant at the 0.05 level. 

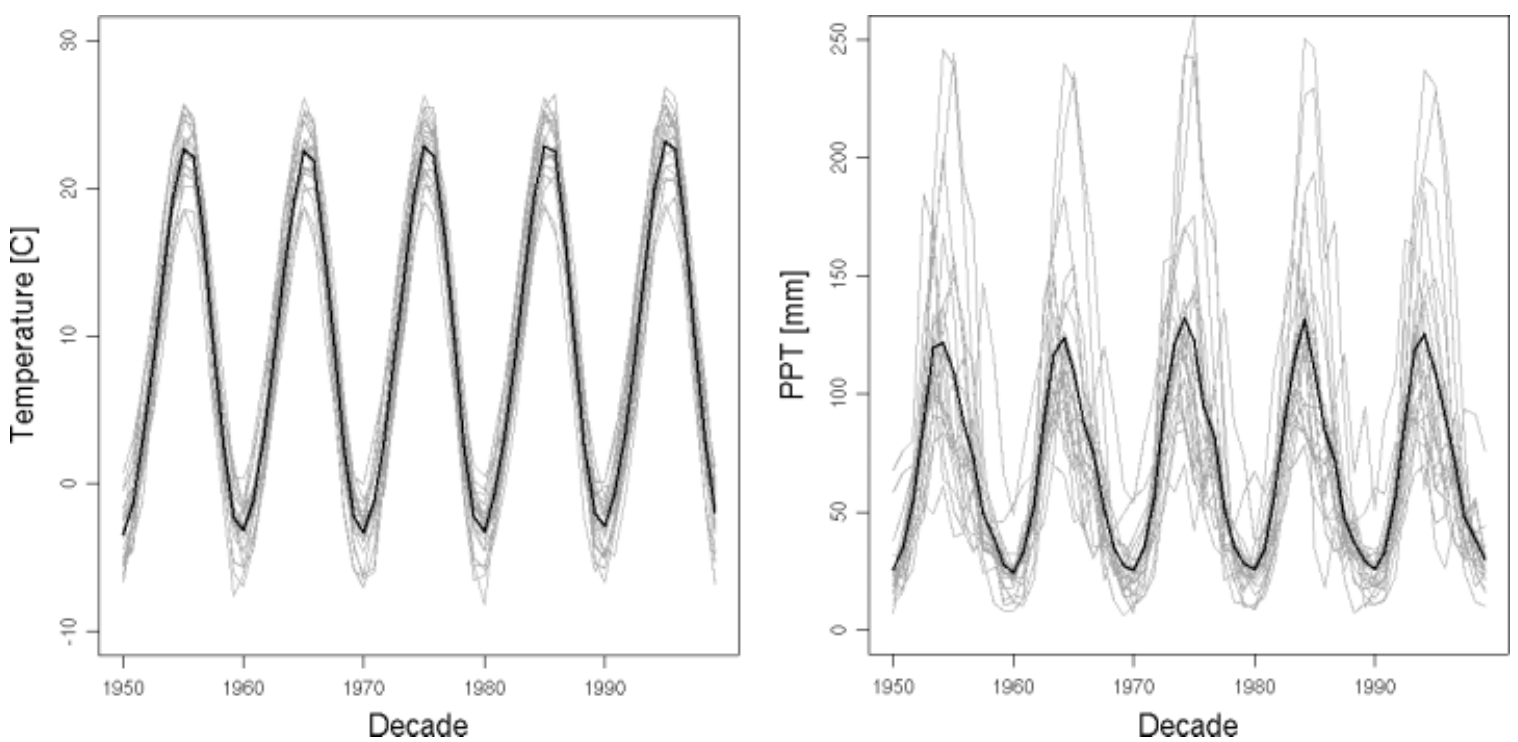

Figure 2. Temperature and precipitation intermodel variability (light grey) and ensemble mean (black) at point 1 for 1950-2000.
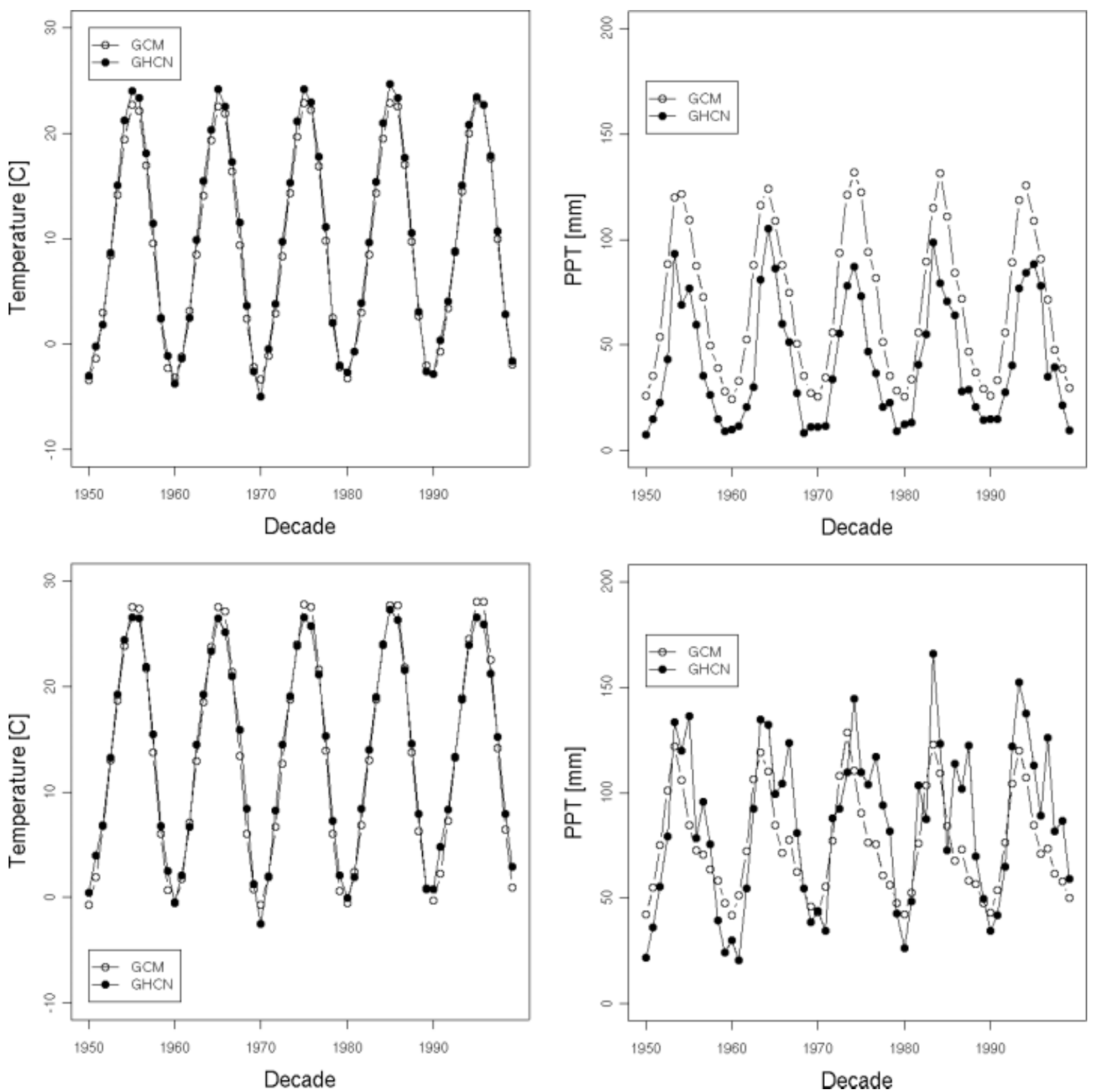

Figure 3. Comparison of ensemble mean global climate model output and Global Historical Climate Network for 1950-2000 for temperature and precipitation (Point 1 top, Point 6 , bottom). 
Table II. Comparison of monthly Global Historical Climate Network and ensemble mean global climate model output for 1950-2000. All slopes are significant at the $p<0.05$ level.

\begin{tabular}{|c|c|c|c|c|c|c|}
\hline \multirow[t]{2}{*}{ Point } & \multicolumn{2}{|c|}{ Precipitation } & \multirow[t]{2}{*}{ RMSE (mm) } & \multicolumn{2}{|c|}{ Temperature } & \multirow[t]{2}{*}{ RMSE (C) } \\
\hline & Slope & $r^{2}$ & & Slope & $r^{2}$ & \\
\hline 1 & 1.1615085 & 0.8932721 & 909 & 0.95583941 & 0.99538582 & 1.0112948 \\
\hline 2 & 0.7919187 & 0.8429086 & 322 & 0.96111321 & 0.990856 & 1.0663241 \\
\hline 3 & 0.6068054 & 0.7157585 & 427 & 1.0061186 & 0.99015711 & 1.0493043 \\
\hline 4 & 1.0331864 & 0.809247 & 1144 & 1.0023816 & 0.99345731 & 1.4767391 \\
\hline 5 & 0.7517395 & 0.7742958 & 356 & 0.99911581 & 0.99238609 & 0.8439416 \\
\hline 6 & 0.5231561 & 0.6359778 & 614 & 1.0664531 & 0.99005011 & 1.2201517 \\
\hline
\end{tabular}

RMSE, root mean square errors.
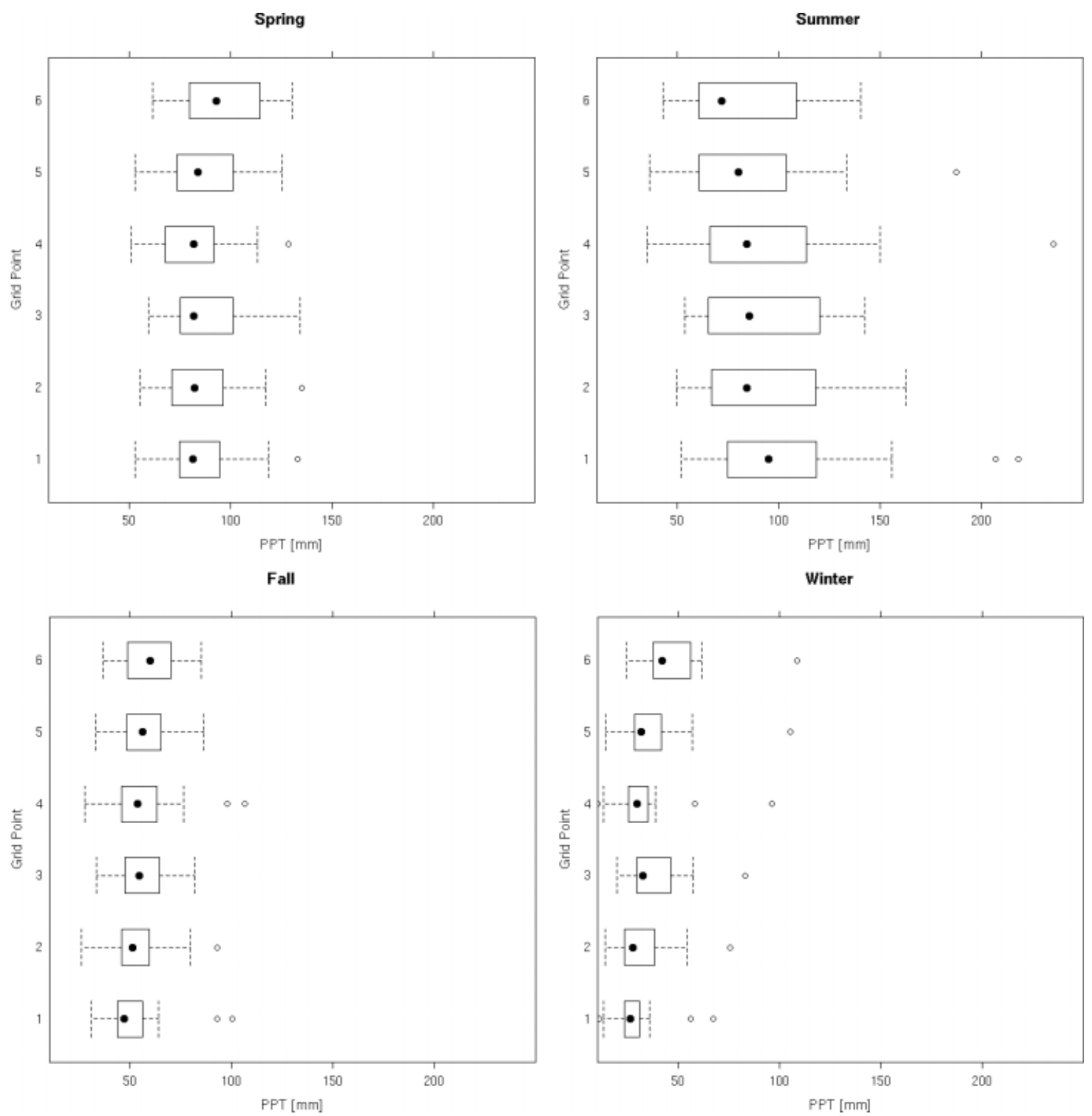

Figure 4. Seasonal precipitation distributions of mean absolute difference between the Global Historical Climate Network and global climate model output for 1950-2000 for each grid cell.

The distributions of linear slopes in seasonal temperatures are shown in Figure 7. All seasons show mean values between 0.01 and $0.02^{\circ} \mathrm{C} /$ year (Table IV). All of the seasonal trends are significant $(p<0.05)$ for the ensemble mean GCM output. Along the southern edge (cells 4-6), there is a general trend of temperatures 

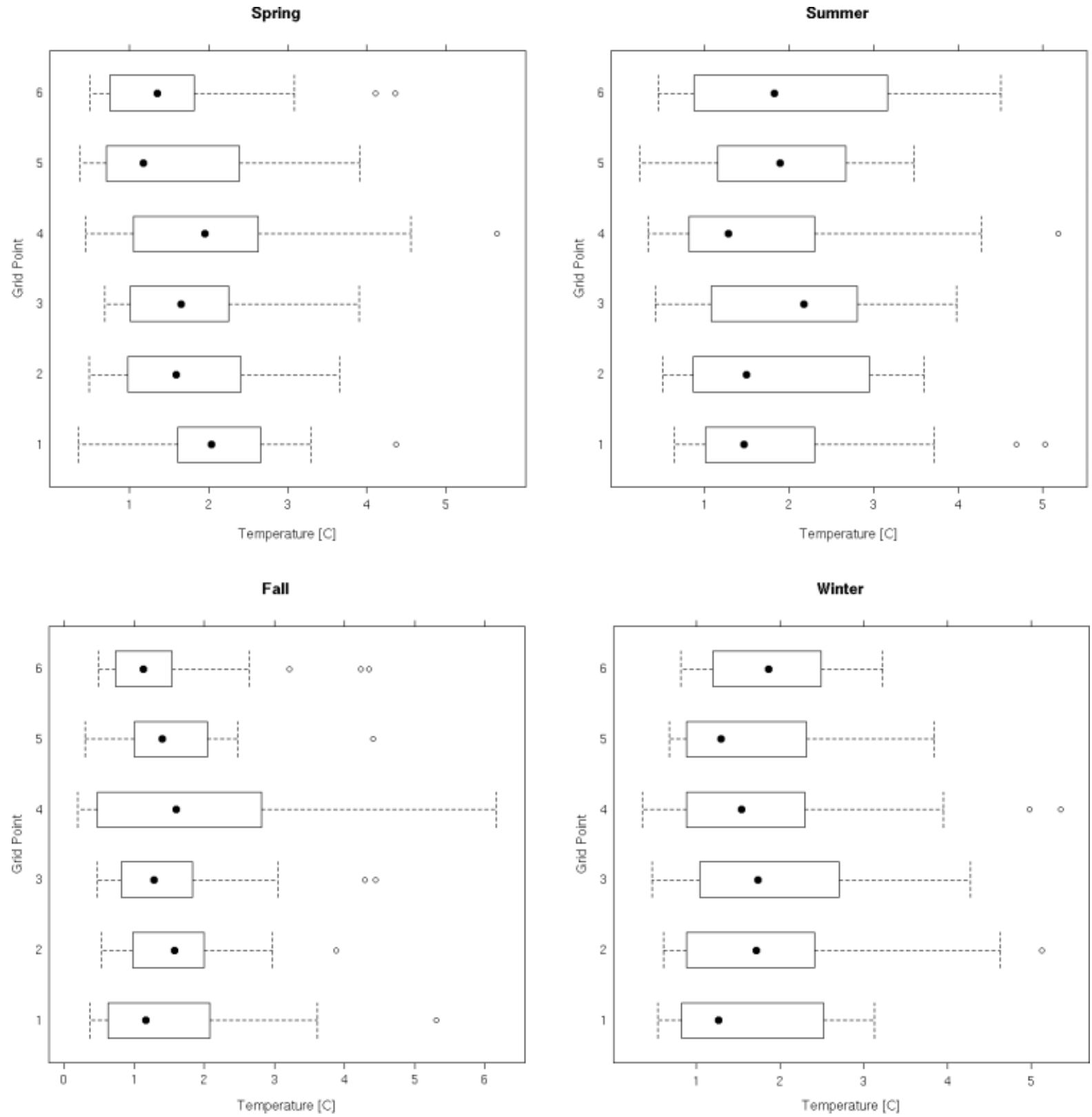

Figure 5. Seasonal temperature distributions of mean absolute difference between the Global Historical Climate Network and global climate model output for 1950-2000 for each grid cell.

increasing more in the western portions of the state for spring, summer and fall. In winter, this trend is reversed with a higher slope in the eastern portion of the state.

The modelled trends are generally larger than the observed trends (shown as triangles), particularly in the Fall when all of the observed trends are lower than the GCM trends. One possible explanation for the discrepancy concerning the Fall temperature trends may be the role of irrigation and land cover change in the region. This will be covered in more detail in Section 4. The observed Spring trends are slightly lower than the majority of GCM derived trends across the region, and (with one exception) the same is true in Winter. The Summer temperature trends generally fall within the majority of GCM trends.

\subsection{Future trends in precipitation and temperature}

Figure 8 shows an example of the intermodel variability for temperature and precipitation, in this case for grid cell 1 for the 21 st century. Ensemble mean precipitation for this cell ranges from approximately $25 \mathrm{~mm}$ in the winter to about $125 \mathrm{~mm}$ in the summer. Temperature shows an increasing trend with time; particularly for winter and summer mean temperatures.

To examine the seasonal trends in the GCM output, box and whisker plots of the seasonal trends in precipitation between 2010 and 2100 are shown in Figure 9. Spring exhibits a clear west to east gradient, increasing from west (cells 1, 4) to east (cells 3, 6). Across the southern portions of the state, the southwestern grid cell (4) exhibits a negative mean trend, but the variability among models is large, while the eastern cell (6) shows 

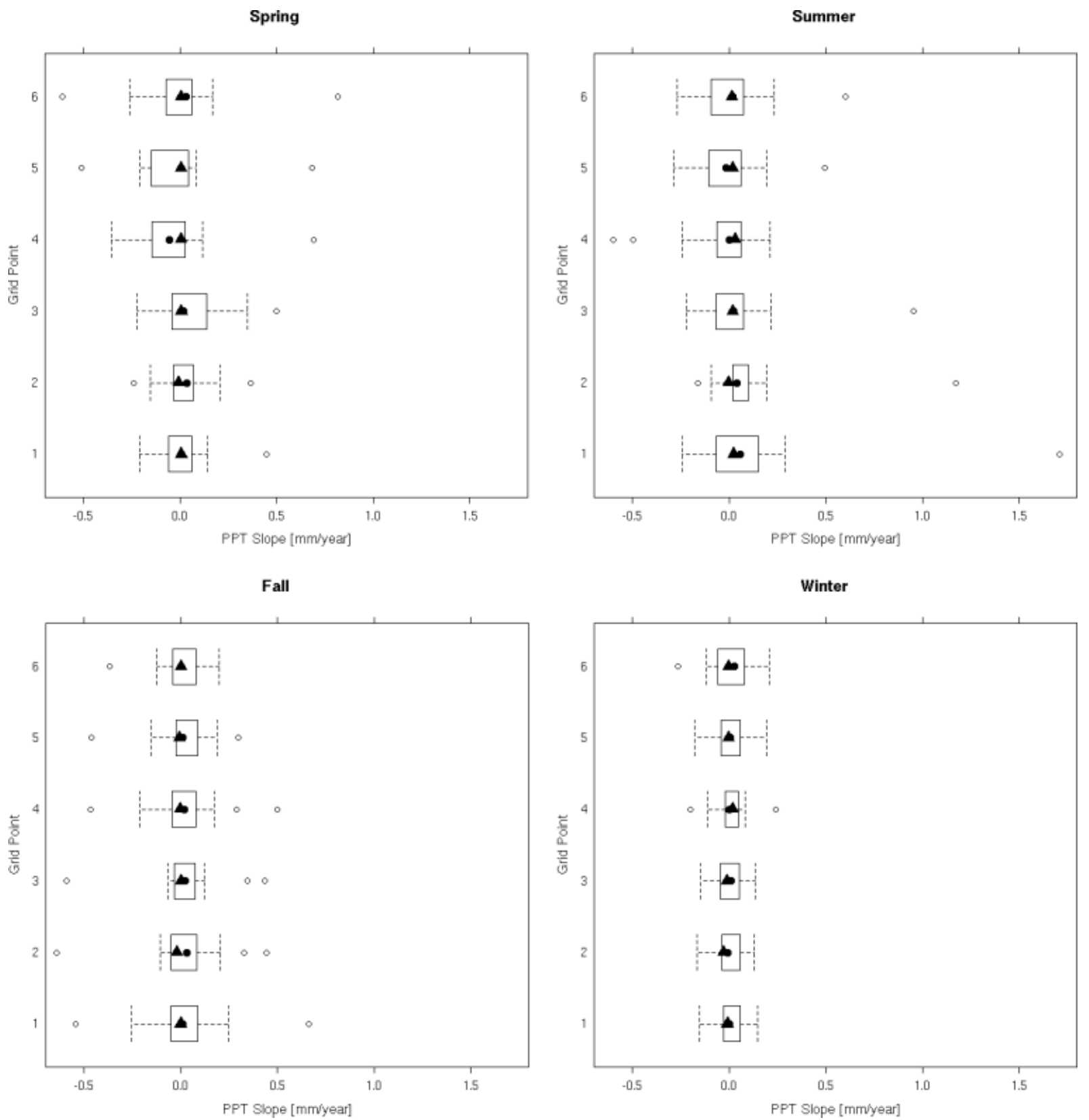

Figure 6. Distribution of seasonal slopes in global climate model precipitation (1950-2000) for each grid cell. Triangles denote observed trends.

a mean of approximately zero. Across the northern half of the state, the mean trend is approximately zero in the west to a slight increase in the east (Table III). Grid cells 2, 3 and 4 exhibit statistically significant trends for spring precipitation.

Summer precipitation exhibits the largest variance between models (Figure 9), but all cells except 4 (southwestern Kansas) exhibit statistically significant decreasing trends in the ensemble mean (Table III). Fall precipitation shows significant decreasing trends in all grid cells. Winter precipitation is generally increasing (all but southeastern Kansas) and is significant across the northern half of the state.

The ensemble mean of air temperature exhibits statistically significant increasing trends for all seasons in all grid cells (Table IV). Winter and spring increases are on the order of 0.035 to $0.04{ }^{\circ} \mathrm{C} /$ year. Summer and fall trends are higher, on the order of 0.042 to $0.048^{\circ} \mathrm{C} /$ year, respectively.

The distributions of seasonal trends in temperature are shown in Figure 10 for 2010-2100. As with the 1950-2000 model output, there is no clear spatial organisation to the trends along either latitude or longitude. While there is seasonal variation in the mean value, the general range of model temperatures is relatively constant across season.

\section{Discussion}

For the period of 1950-2000, GCM output for air temperature matches observations extremely well (Table II). The observed trends from 1950 to 2000 in the region 
Table III. Linear precipitation trends (mm/year) and associated $r^{2}$ values.

\begin{tabular}{|c|c|c|c|c|c|c|c|c|c|c|}
\hline \multirow{2}{*}{$\begin{array}{l}\text { Grid } \\
\text { Cell }\end{array}$} & \multicolumn{2}{|c|}{ Decadal } & \multicolumn{2}{|c|}{ Winter } & \multicolumn{2}{|c|}{ Spring } & \multicolumn{2}{|c|}{ Summer } & \multicolumn{2}{|c|}{ Fall } \\
\hline & Trend & $r^{2}$ & Trend & $r^{2}$ & Trend & $r^{2}$ & Trend & $r^{2}$ & Trend & $r^{2}$ \\
\hline \multicolumn{11}{|c|}{ GHCN (1950-2000) } \\
\hline 1 & 8.54E-2 & 0.00 & $5.86 \mathrm{E}-2$ & 0.02 & $2.37 \mathrm{E}-2$ & 0.00 & $1.38 \mathrm{E}-1$ & 0.01 & $1.22 \mathrm{E}-1$ & 0.02 \\
\hline 2 & $5.47 \mathrm{E}-2$ & 0.00 & $-9.18 \mathrm{E}-2$ & 0.02 & $1.76 \mathrm{E}-1$ & 0.01 & $-2.74 \mathrm{E}-2$ & 0.00 & $1.62 \mathrm{E}-1$ & 0.01 \\
\hline 3 & $-1.22 \mathrm{E}-1$ & 0.00 & $-3.37 \mathrm{E}-2$ & 0.00 & $-4.28 \mathrm{E}-2$ & 0.00 & $-4.94 \mathrm{E}-1$ & 0.04 & $8.20 \mathrm{E}-2$ & 0.00 \\
\hline 4 & $1.86 \mathrm{E}-1$ & 0.01 & $8.74 \mathrm{E}-2$ & 0.04 & $1.94 \mathrm{E}-1$ & 0.02 & $2.68 \mathrm{E}-1$ & 0.02 & $1.97 \mathrm{E}-1$ & 0.05 \\
\hline 5 & $3.11 \mathrm{E}-1$ & 0.02 & 2.27E-1 & 0.09 & 6.09E-1 & 0.10 & $1.39 \mathrm{E}-1$ & 0.00 & $2.69 \mathrm{E}-1$ & 0.03 \\
\hline 6 & 4.33E-1 & 0.04 & 4.18E-1 & 0.11 & 6.54E-1 & 0.09 & $4.31 \mathrm{E}-2$ & 0.00 & $6.16 \mathrm{E}-1$ & 0.05 \\
\hline \multicolumn{11}{|c|}{ GCM (1950-2000) } \\
\hline 1 & $1.86 \mathrm{E}-2$ & 0.00 & $3.32 \mathrm{E}-3$ & 0.01 & $1.70 \mathrm{E}-2$ & 0.05 & $1.20 \mathrm{E}-1$ & 0.27 & $2.00 \mathrm{E}-2$ & 0.04 \\
\hline 2 & $1.34 \mathrm{E}-2$ & 0.00 & $-1.36 \mathrm{E}-3$ & 0.00 & $2.63 \mathrm{E}-2$ & 0.15 & $9.08 \mathrm{E}-2$ & 0.26 & $2.45 \mathrm{E}-2$ & 0.20 \\
\hline 3 & $1.20 \mathrm{E}-2$ & 0.00 & $7.88 \mathrm{E}-4$ & 0.00 & $5.32 \mathrm{E}-2$ & 0.45 & $5.82 \mathrm{E}-2$ & 0.12 & $2.44 \mathrm{E}-2$ & 0.22 \\
\hline 4 & $-2.58 \mathrm{E}-2$ & 0.00 & $2.36 \mathrm{E}-3$ & 0.01 & $-4.34 \mathrm{E}-2$ & 0.17 & $-4.94 \mathrm{E}-2$ & 0.46 & $1.31 \mathrm{E}-2$ & 0.03 \\
\hline 5 & $-2.45 \mathrm{E}-2$ & 0.00 & $-5.53 \mathrm{E}-3$ & 0.02 & $-2.12 \mathrm{E}-2$ & 0.04 & $9.47 \mathrm{E}-5$ & 0.00 & $8.16 \mathrm{E}-3$ & 0.02 \\
\hline 6 & $-2.54 \mathrm{E}-2$ & 0.00 & $8.71 \mathrm{E}-3$ & 0.03 & $9.22 \mathrm{E}-3$ & 0.01 & $1.23 \mathrm{E}-2$ & 0.01 & $4.04 \mathrm{E}-3$ & 0.01 \\
\hline \multicolumn{11}{|c|}{ GCM (2010-2100) } \\
\hline 1 & $-1.11 \mathrm{E}-8$ & 0.17 & $3.41 \mathrm{E}-2$ & 0.74 & $-1.56 \mathrm{E}-3$ & 0.00 & $-7.34 \mathrm{E}-2$ & 0.65 & $-4.38 \mathrm{E}-2$ & 0.65 \\
\hline 2 & $-9.08 \mathrm{E}-9$ & 0.16 & 2.38E-2 & 0.52 & 3.60E-2 & 0.46 & $-7.18 E-2$ & 0.62 & $-4.76 E-2$ & 0.72 \\
\hline 3 & $-4.99 \mathrm{E}-9$ & 0.12 & 2.37E-2 & 0.70 & $7.48 \mathrm{E}-2$ & 0.82 & $-6.05 \mathrm{E}-2$ & 0.53 & $-4.05 \mathrm{E}-2$ & 0.46 \\
\hline 4 & $-1.69 \mathrm{E}-8$ & 0.22 & $1.46 \mathrm{E}-2$ & 0.28 & $-6.06 \mathrm{E}-2$ & 0.59 & $-8.44 \mathrm{E}-2$ & 0.44 & $-4.79 \mathrm{E}-2$ & 0.84 \\
\hline 5 & $-1.69 \mathrm{E}-8$ & 0.23 & $3.56 \mathrm{E}-3$ & 0.02 & $-9.68 \mathrm{E}-3$ & 0.03 & -8.88E-2 & 0.61 & $-6.08 E-2$ & 0.81 \\
\hline 6 & $-1.70 \mathrm{E}-8$ & 0.24 & $-6.16 \mathrm{E}-3$ & 0.04 & $2.03 \mathrm{E}-2$ & 0.06 & $-8.64 \mathrm{E}-2$ & 0.57 & $-5.49 E-2$ & 0.61 \\
\hline
\end{tabular}

GHCN, Global Historical Climate Network; GCM, global climate model.

Bold values indicate significant at $p<0.05$.

are weak, whereas all of the GCM trends are significantly increasing temperatures over the same simulated time period. The precipitation also agrees well between the ensemble mean and observations, but not quite as well as the temperature; with few trends being significant for the observations and none for the model output. These trends agree well with the observed literature (e.g. Grundstein, 2008)

Overall, we have confidence in the model ensemble for simulating the Kansas climate. There are several potential mitigating factors that will complicate the agreement between the models and reality. One factor is that the GHCN station data may not accurately represent the true climate of the region due to site location (Pielke et al., 2007) or general representativeness of the site (Pielke et al., 2002). In addition, the act of kriging the station data can potentially induce error in the composite values.

Another factor that may decrease the agreement between the observations and model output is the representation of the land cover in the GCMs. In eastern Kansas, there has been a trend toward both increasing urbanisation as well as increased woody encroachment (Heisler et al., 2003). These factors will contribute differently toward temperature trends through changes in surface radiation budget (albedo, heat capacity) and water cycling (evapotranspiration). In western Kansas, the dominant land use is agriculture, with a significant portion of this being irrigated (on the order of $25 \%$ ). Generally, irrigation is not simulated in GCMs, preventing them from simulating climate impacts associated with this process (e.g. Moore and Rojstaczer, 2001). This means that the models also cannot simulate the resultant influx of atmospheric moisture following evapotranspiration. Irrigation will likely result in cooling (or reduce warming) in the GHCN observations over western Kansas, and could result in an increase in the eastern Kansas precipitation dependent on regional circulation patterns.

The 21st century simulations show temperature trends approximately double the increases simulated for the 1950-2000 period. All of these values are statistically significant. In addition, many of the precipitation trends are significant particularly for the summer and fall.

Thus, we can begin to examine the impacts on regional climate in Kansas from the multimodel ensemble mean temperature and precipitation seasonal trends. Based on the multimodel GCM simulations, the state will warm in all seasons. Winter temperatures will likely see a transition to above freezing mean temperatures by the end of the century (Figure 8). This will have a profound impact on the propagation of diseases in the region (IPCC, 2007 Report II chapter 5, section 5.4.1.4), perhaps even more so if this continues the observed trend of greatest increases in minimum temperatures (Robeson, 2004; Alexander et al., 2006); something that will increase the costs of agricultural production. Winter precipitation will likely increase slightly also following observed trends (Garbrecht et al., 2004; Grundstein, 2008, 2009). 

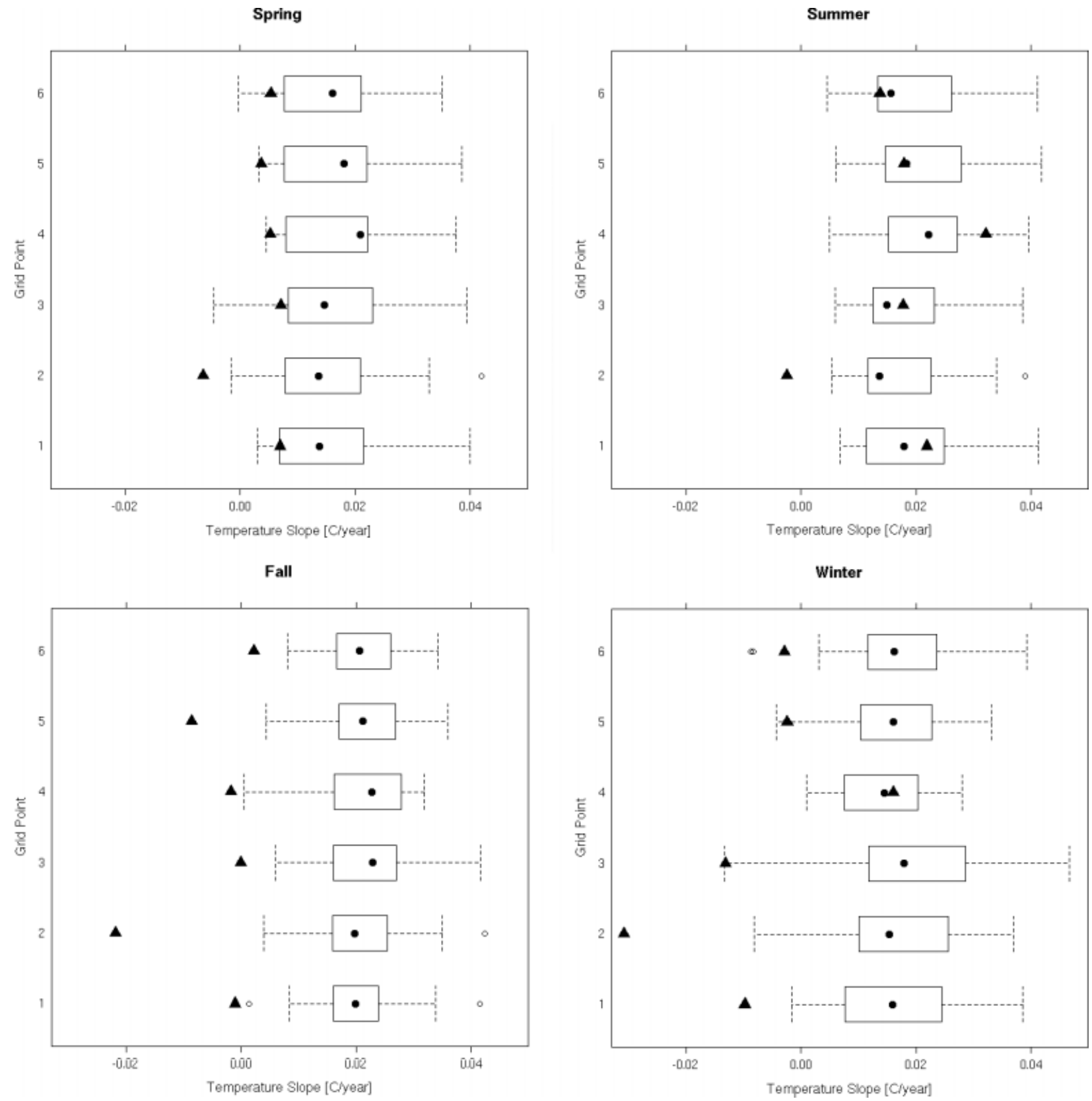

Figure 7. Distribution of seasonal slopes for global climate model temperature (1950-2000) for each grid cell. Triangles denote observed trends.

Spring precipitation in the western regions of the state will likely decrease. This, in combination with increased air temperatures, will likely result in a greater water deficit compared with current conditions. The decrease in precipitation becomes larger in the summer, which accompanied by the rising simmer temperatures will lead to sufficient increases in moisture deficits to likely affect agricultural productivity negatively. Fall temperatures increase by similar magnitudes as the summer, but the precipitation decreases at a lower rate. For agricultural production in the region, these changes over the growing season signify greater water requirements assuming crop types are not changed to species requiring less water. Although these results suggest a lengthening of the growing season and increases in growing degree days for the region, these potential improvements in crop productivity are offset by reduced water availability for the increased transpiration need (Sacks et al., 2007).

Water availability in western Kansas is not a certainty; therefore, adaptation by increasing irrigation rates may not be an option. The region already draws heavily from groundwater (the Ogallala Aquifer), where it has been shown that more efficient irrigation does not necessarily result in decreased depletion because of increases in the total area of irrigation (McMahon et al., 2003; Scanlon et al., 2005). Alterations in land use may also result in changing groundwater quality, primarily through increased chloride and nitrate concentrations (Scanlon et al., 2005). The combination of altering subsurface hydrology and precipitation events will likely have a negative impact on aquatic ecosystems in the region (Covich et al., 1997; Dodds et al., 2004). 
Table IV. Linear temperature trends $\left({ }^{\circ} \mathrm{C} /\right.$ year $)$ and associated $r^{2}$ values.

\begin{tabular}{|c|c|c|c|c|c|c|c|c|c|c|}
\hline \multirow{2}{*}{$\begin{array}{l}\text { Grid } \\
\text { Cell }\end{array}$} & \multicolumn{2}{|c|}{ Decadal } & \multicolumn{2}{|c|}{ Winter } & \multicolumn{2}{|c|}{ Spring } & \multicolumn{2}{|c|}{ Summer } & \multicolumn{2}{|c|}{ Fall } \\
\hline & Trend & $r^{2}$ & Trend & $r^{2}$ & Trend & $r^{2}$ & Trend & $r^{2}$ & Trend & $r^{2}$ \\
\hline \multicolumn{11}{|c|}{ GHCN (1950-2000) } \\
\hline 1 & $4.48 \mathrm{E}-3$ & 0.00 & $6.92 \mathrm{E}-3$ & 0.00 & $2.19 \mathrm{E}-2$ & 0.07 & $-1.13 \mathrm{E}-3$ & 0.00 & $-9.83 \mathrm{E}-3$ & 0.02 \\
\hline 2 & $-1.54 \mathrm{E}-2$ & 0.00 & $-6.47 \mathrm{E}-3$ & 0.00 & $-2.51 \mathrm{E}-3$ & 0.00 & $-2.18 \mathrm{E}-2$ & 0.09 & $-3.08 \mathrm{E}-2$ & 0.14 \\
\hline 3 & $2.93 \mathrm{E}-3$ & 0.00 & 7.11E-3 & 0.00 & $1.78 \mathrm{E}-2$ & 0.04 & $-1.26 \mathrm{E}-4$ & 0.00 & $-1.31 \mathrm{E}-2$ & 0.03 \\
\hline 4 & $1.29 \mathrm{E}-2$ & 0.00 & $5.24 \mathrm{E}-3$ & 0.00 & $3.21 \mathrm{E}-2$ & 0.13 & $-1.77 \mathrm{E}-3$ & 0.00 & $1.60 \mathrm{E}-2$ & 0.04 \\
\hline 5 & $2.64 \mathrm{E}-3$ & 0.00 & $3.63 \mathrm{E}-3$ & 0.00 & $1.79 \mathrm{E}-2$ & 0.04 & $-8.60 \mathrm{E}-3$ & 0.02 & $-2.37 \mathrm{E}-3$ & 0.00 \\
\hline 6 & $4.59 \mathrm{E}-3$ & 0.00 & $5.35 \mathrm{E}-3$ & 0.00 & $1.37 \mathrm{E}-2$ & 0.03 & $2.19 \mathrm{E}-3$ & 0.00 & $-2.88 \mathrm{E}-3$ & 0.00 \\
\hline \multicolumn{11}{|c|}{ GCM (1950-2000) } \\
\hline 1 & $2.99 \mathrm{E}-2$ & 0.067 & $1.61 \mathrm{E}-2$ & 0.88 & 1.53E-2 & 0.705 & 1.93E-2 & 0.852 & 2.03E-2 & 0.81 \\
\hline 2 & $3.15 \mathrm{E}-2$ & 0.067 & $1.66 \mathrm{E}-2$ & 0.817 & 1.53E-2 & 0.639 & 1.86E-2 & 0.861 & 2.09E-2 & 0.78 \\
\hline 3 & $3.37 \mathrm{E}-2$ & 0.067 & 1.79E-2 & 0.828 & $1.55 \mathrm{E}-2$ & 0.626 & $1.89 \mathrm{E}-2$ & 0.882 & 2.18E-2 & 0.77 \\
\hline 4 & $2.97 \mathrm{E}-2$ & 0.066 & $1.48 \mathrm{E}-2$ & 0.836 & $1.75 \mathrm{E}-2$ & 0.774 & $2.22 \mathrm{E}-2$ & 0.862 & 2.09E-2 & 0.82 \\
\hline 5 & $3.05 \mathrm{E}-2$ & 0.065 & $1.50 \mathrm{E}-2$ & 0.78 & $1.64 \mathrm{E}-2$ & 0.702 & 2.03E-2 & 0.854 & 2.12E-2 & 0.79 \\
\hline 6 & $3.13 \mathrm{E}-2$ & 0.065 & $1.56 \mathrm{E}-2$ & 0.779 & 1.53E-2 & 0.666 & $1.92 \mathrm{E}-2$ & 0.849 & 2.10E-2 & 0.76 \\
\hline \multicolumn{11}{|c|}{ GCM (2010-2100) } \\
\hline 1 & $4.03 \mathrm{E}-2$ & 0.131 & $3.59 \mathrm{E}-2$ & 0.995 & 3.49E-2 & 0.985 & 4.67E-2 & 0.981 & 4.27E-2 & 0.984 \\
\hline 2 & $4.16 \mathrm{E}-2$ & 0.128 & 3.82E-2 & 0.995 & 3.53E-2 & 0.986 & 4.73E-2 & 0.979 & 4.31E-2 & 0.983 \\
\hline 3 & $4.30 \mathrm{E}-2$ & 0.125 & 4.07E-2 & 0.994 & 3.62E-2 & 0.987 & $4.75 \mathrm{E}-2$ & 0.978 & 4.35E-2 & 0.982 \\
\hline 4 & $4.06 \mathrm{E}-2$ & 0.13 & $3.44 \mathrm{E}-2$ & 0.995 & 3.79E-2 & 0.982 & 4.77E-2 & 0.981 & 4.39E-2 & 0.985 \\
\hline 5 & $4.14 \mathrm{E}-2$ & 0.128 & $3.57 \mathrm{E}-2$ & 0.995 & 3.67E-2 & 0.982 & $4.86 \mathrm{E}-2$ & 0.978 & 4.42E-2 & 0.983 \\
\hline 6 & $4.18 \mathrm{E}-2$ & 0.126 & $3.64 \mathrm{E}-2$ & 0.995 & $3.55 \mathrm{E}-2$ & 0.985 & 4.89E-2 & 0.979 & $4.37 \mathrm{E}-2$ & 0.983 \\
\hline
\end{tabular}

Bold indicates significant at $p<0.05$

In terms of natural grasslands in Kansas, the increased temperature and decreased precipitation will likely result in an increase in $\mathrm{C}_{4}$ grass species (Knapp et al., 2001). In fact, this is already being observed at the Nelson Environmental Study Area, north of Lawrence KS, where $\mathrm{C}_{4}$ grasses have increased in the last 5 years (Foster et al., in press). When combined with the urbanisation and continued woody encroachment, the future for water cycling in the eastern portions of the state is uncertain.

A mitigating factor for the interactions between natural grasslands and woody encroachment will be the role of soil moisture. Using a regional climate model, we (Jones and Brunsell, 2009a, 2009b) have shown that the area experiences positive soil moisture-precipitation feedbacks. This implies that alterations to the precipitation regime will likely be exacerbated. One of the dominant factors that will likely determine the propagation of $\mathrm{C}_{4}$ species in the region will be alterations to the timing of precipitation events. Since we are focusing on seasonal trends in precipitation, we are unable to examine the likely changes beyond seasonal magnitudes. However, changes in natural species composition will have agricultural significance due to the large amount of cattle and bison production in the state.

Future trends in precipitation and temperature will also be heavily influenced by changes in local land cover (Feddema et al., 2005b). Urban heat island affects and accelerated runoff rates associated with urbanisation in eastern Kansas may become more significant. These will likely cause the temperature trends presented here to be low (assuming that current trends in population and urbanisation continue). Urbanisation is known to alter regional air temperatures (Oke, 1982), precipitation patterns (Rozoff et al., 2003) and carbon cycle dynamics (White et al., 2002). Again, these issues are not specifically addressed here, but are likely to exacerbate the local expression of the trends in the GCM output.

\section{Summary}

Understanding the impacts of future climate change in Kansas is important for agricultural and other socioeconomic sectors. To quantify what some of these impacts are, we examined seasonal trends in air temperature and precipitation patterns from 21 GCMs used in the IPCC AR4. To ascertain the performance of the models, we compared model output to kriged meteorological station data from 1950 to 2000 . Then, the linear trends for the 21 st century were examined.

Results indicate that temperatures are likely to warm in all seasons, with the largest trends being on the order of $0.04^{\circ} \mathrm{C} /$ year in summer and fall. Precipitation is likely to increase slightly in winter and decrease in summer and fall. These changes have profound implications for both natural ecosystems and agricultural land uses in the region.

GCMs are a simplification of the natural world, and therefore many processes are either missing or are not adequately represented. However, many of the factors that are currently dominating local land-atmosphere 

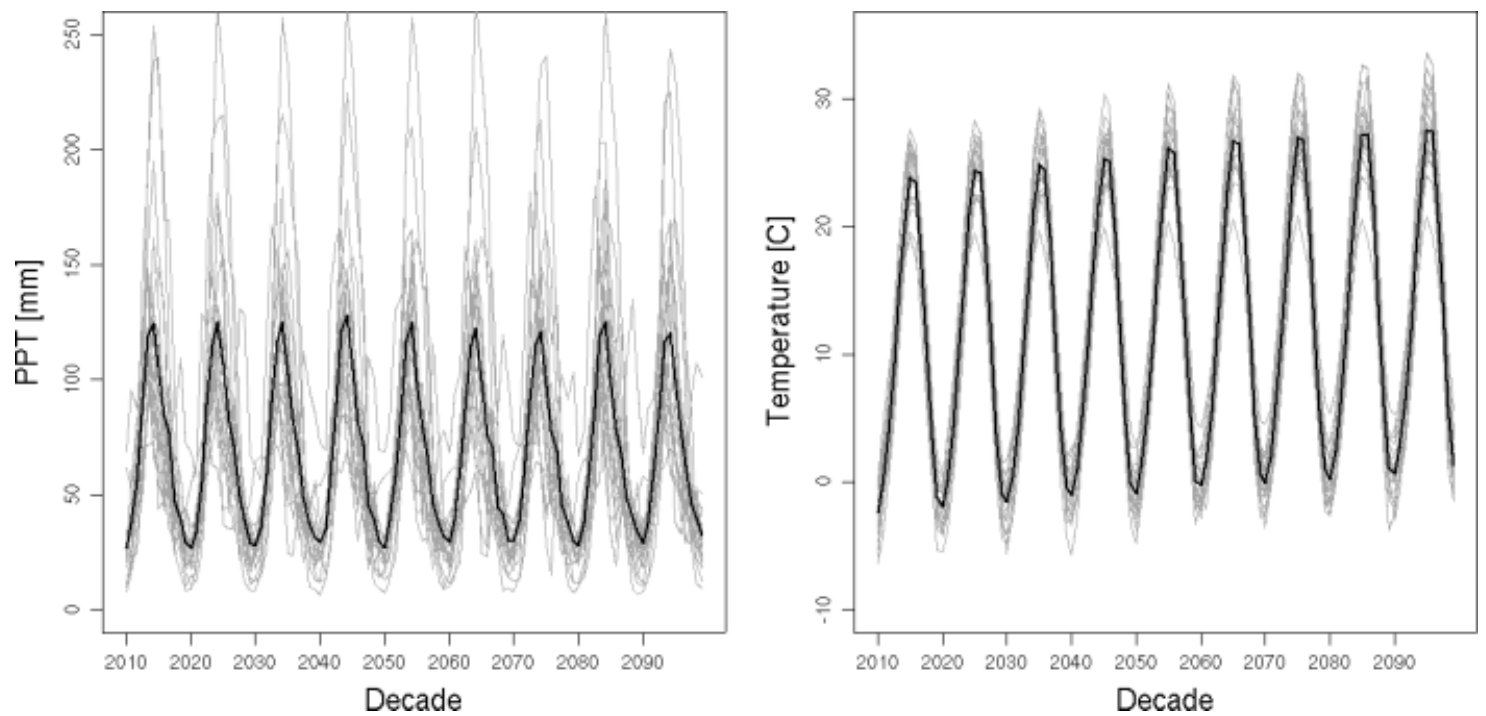

Figure 8. Intermodel variability for 2010-2100 for precipitation and temperature at point 1 (light grey), and ensemble mean (black).
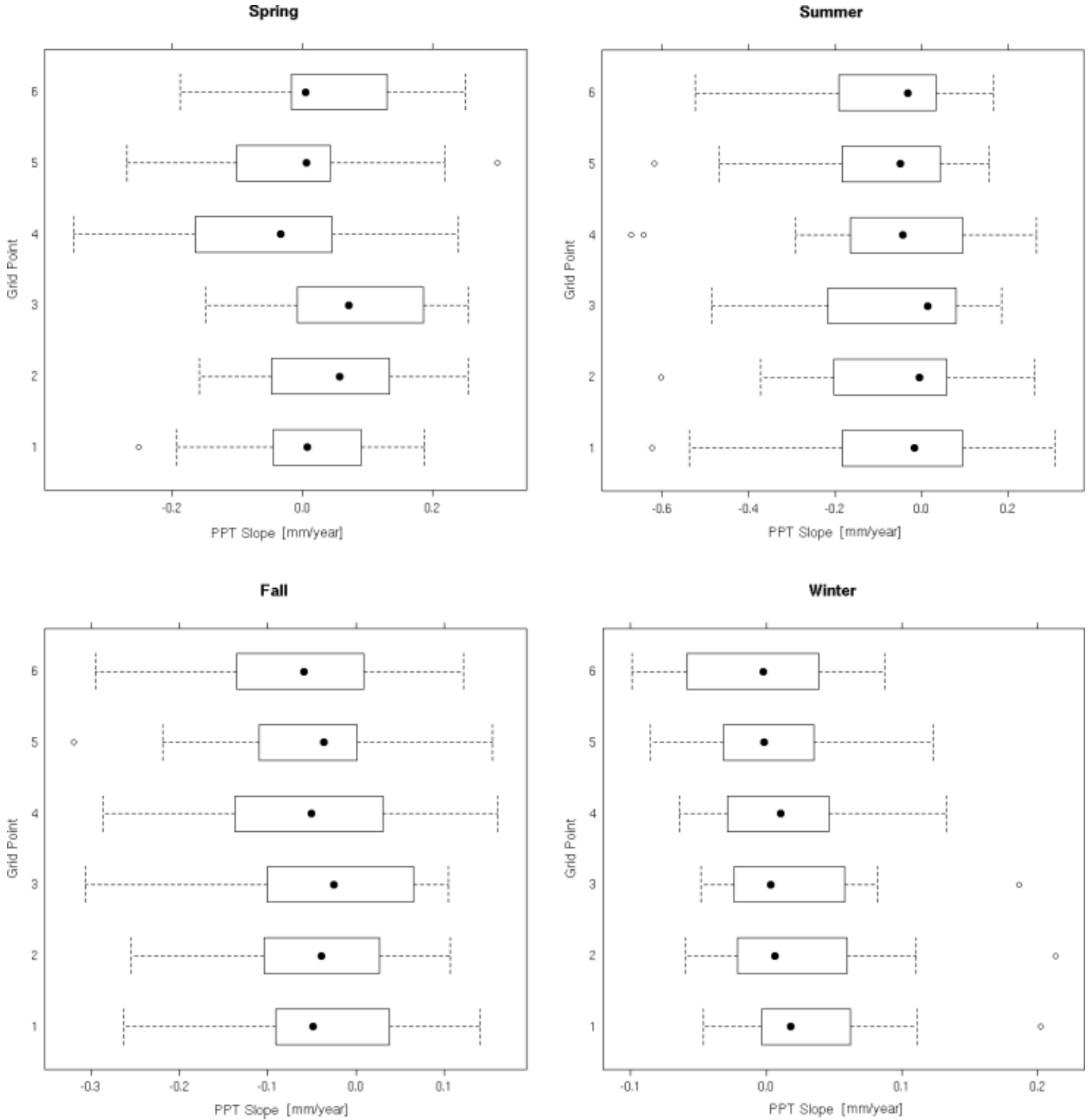

Figure 9. As Figure 6, for 2010-2090. 

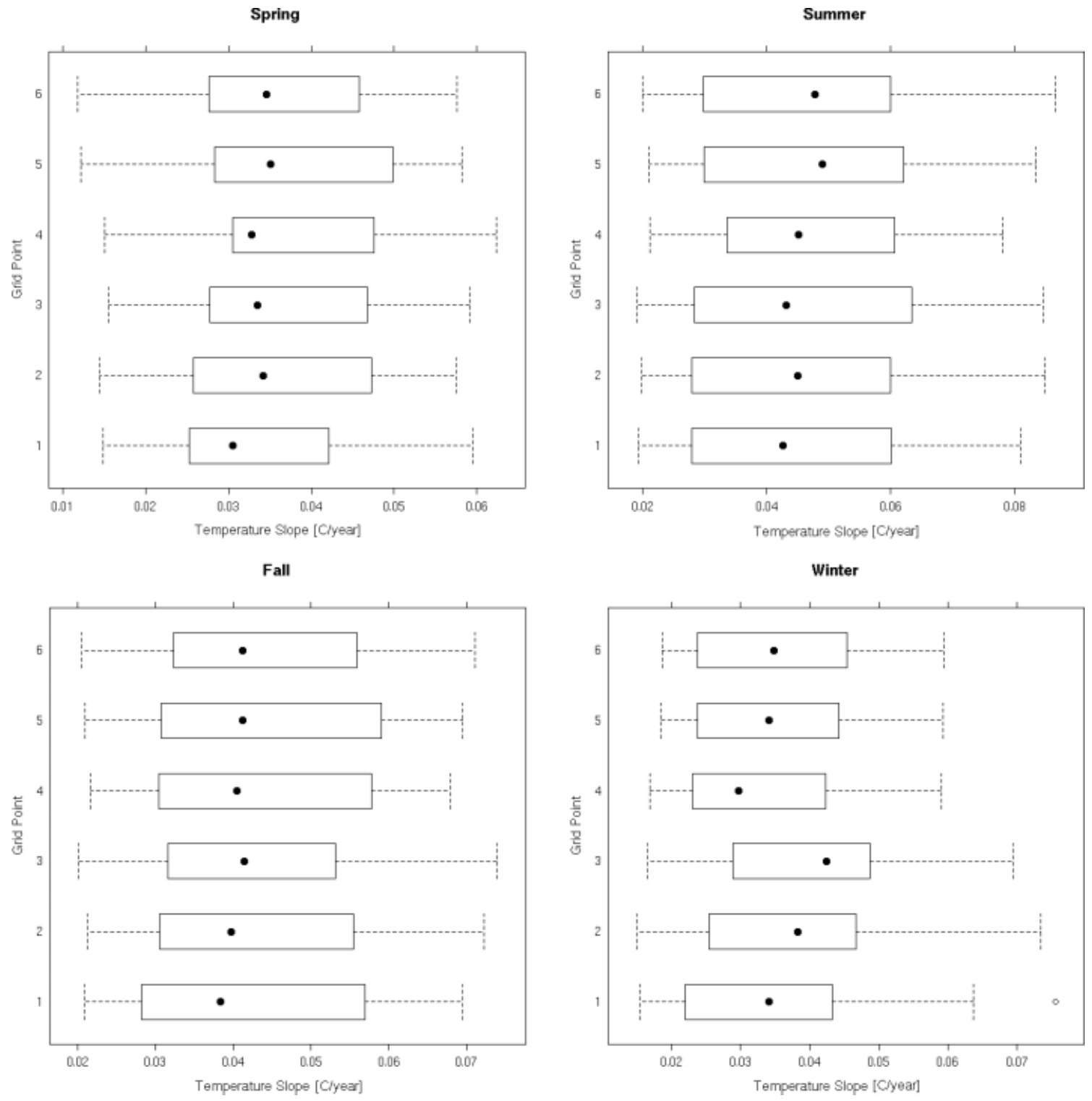

Figure 10. As Figure 7, for 2010-2090.

interactions in Kansas (e.g. urbanisation) are likely to enhance the predicted trends rather than offset them.

\section{Acknowledgements}

This work was funded through the Land Institute Climate and Energy Project (NFP \#49780-720) and the National Science Foundation EPSCoR program (NSF EPS \#0553722). We thank Julie Arblaster, Claudia Tibaldi and Gary Strand at the National Center for Atmospheric Research for providing the global climate model output for this study. In addition, we thank the two anonymous reviewers whose comments have improved this manuscript.

\section{References}

Adegoke JO, Pielke R, Carleton AM. 2007. Observational and modeling studies of the impacts of agriculture-related land use change on planetary boundary layer processes in the central US. Agricultural and Forest Meteorology 142: 203-215.
Adegoke JO, Pielke RA, Eastman J, Mahmood R, Hubbard KG. 2003. Impact of irrigation on midsummer surface fluxes and temperature under dry synoptic conditions: a regional atmospheric model study of the U.S. high plains. Monthly Weather Review 131: 556-564.

Alexander LV, Zhang X, Peterson TC, Caesar J, Gleason B, Klein Tank AMG, Haylock M, Collins D, Trewin B, Rahimzadeh F, Tagipour A, Ambenje P, Rupa Kumar K, Revadekar J, Griffiths G. 2006. Global observed changes in daily climate extremes of temperature and precipitation. Journal Geophysical Research 111: D05109.

Alward RD, Detling JK, Milchunas DG. 1999. Grassland vegetation changes and nocturnal global warming. Science 283: 229-231.

Bonan GB. 1999. Frost followed the plow: impacts of deforestation on the climate of the United States. Ecological Applications 9: $1305-1315$.

Brunsell NA. 2006. Characterization of land-surface precipitation feedback regimes with remote sensing. Remote Sensing of Environment 100: 200-211.

Carter DB, Mather JR. 1966. Climatic classification for environmental biology. Publications in Climatology 19(1): 305-395.

Changnon SA, Kunkel KE, Winstanley D. 2002. Climate factors that caused the unique tall grass prairie in the Central United States. Physical Geography 23(4): 259-280.

Claussen M, Brovkin V, Ganapolski A. 2001. Biogeophysical versus biogeochemical feedbacks of large-scale land cover change. Geophysical Research Letters 28(6): 1011-1014. 
Covich AP, Fritz SC, Lamb PJ, Marzolf RD, Matthews WJ, Poiani KA, Prepas EE, Richman MB, Winter TC. 1997. Potential effects of climate change on aquatic ecosystems of the Great Plains of North America. Hydrological Processes 11: 993-1021.

Cox PM, Betts RA, Jones CD, Spall SA, Totterdell IJ. 2000. Acceleration of global warming due to carbon-cycle feedbacks in a coupled climate model. Nature 408: 184-187.

Dirmeyer PA, Kinter JL III. 2009. The 'Maya Express': floods in the U.S. Midwest. EQS Transactions 90(12): 101-102.

Dodds WK, Gido K, Whiles MR, Fritz KM, Matthews MJ. 2004. Life on the edge: the ecology of Great Plains prairie streams. BioScience 54: $205-216$.

Easterling WE, Crosson PR, Rosenberg NJ, McKenney MS, Katz LA, Lemon KM. 1993. Agricultural impacts of and responses to climate change in the Missouri-Iowa-Nebraska-Kansas (MINK) region. Climatic Change 24: 23-61.

Fay PA, Carlisle JD, Knapp AK, Blair JM, Collins SL. 2003. Productivity responses to altered rainfall patterns in a C4-dominated grassland. Oecologia 137: 245-251.

Feddema J, Oleson K, Bonan G, Mearns L, Washington W, Meehl G, Nychka D. 2005a. A comparison of a GCM response to historical anthropogenic land cover change and model sensitivity to uncertainty in present-day land cover representations. Climatic Dynamics 25: $581-609$.

Feddema JJ, Oleson KW, Bonan GB, Mearns LO, Buja LE, Meehl GA, Washington WM. 2005b. The importance of land-cover change in simulating future climates. Science 310: 1674-1678.

Feng S, Oglesby RJ, Rowe CM, Loope DB, Hu Q. 2008. Atlantic and Pacific SST influences on medieval drought in North America simulated by the community atmospheric model. Journal of Geophysical Research 113: D11101.

Foster BL, Kindscher K, Houseman GR, Murphy CA. Effects of hay management and native sowing on community structure and biomass: implications for the restoration of former HILD grasslands to LIHD hay meadows. Ecological Applications : (in press).

Feddema JJ. 2005. A revised thornthwaite type global climate classification. Physical Geography 26(6): 442-466.

Frank DA, Inouye RS. 1994. Temporal variation in actual evapotranspiration of terrestrial ecosystems: patterns and ecological implications. Journal of Biogeography 21: 401-411.

Garbrecht JD, Rossel FE. 2002. Decade-scale precipitation increase in the Great Plains at the end of the 20th century. Journal of Hydrologic Engineering 7(1): 64-75.

Garbrecht JD, Van Liew M, Brown GO. 2004. Trends in precipitation, streamflow, and evapotranspiration in the Great Plains of the United States. Journal of Hydrologic Engineering 9(5): 360-367.

Grundstein A. 2008. Assessing climate change in the contiguous United States using a modified Thornthwaite climate classification scheme. Professional Geographer 60(3): 398-412.

Grundstein A. 2009. Evaluation of climate change over the continental United States using a moisture index. Climatic Change 93(1): $103-115$.

Heisler JL, Briggs JM, Knapp AK. 2003. Long-term patterns of shrub expansion in a C4-dominated grassland: fire frequency and the dynamics of shrub cover and abundance. American Journal of Botany 90: $423-428$

Heistermann M, Muller C, Ronneberger K. 2006. Land in sight? Achievements, deficits and potentials of continental to global scale land-use modeling. Agriculture, Ecosystems and Environment 114: $141-158$.

Hopkins A, del Prado A. 2007. Implications of climate change for grassland in Europe: impacts, adaptations and mitigation options: a review. Grass and Forage Science 62: 118-126.

Howden SM, Soussana JF, Tubiello FN, Chhetri N, Dunlop M, Meinke H. 2007. Adapting agriculture to climate change. Proceedings of the National Academy of Sciences of the USA 104: 19691-19696, DOI:10.1073pnas.0701890104.

Intergovernmental Panel on Climate change. 2000. Special Report on Emissions Scenarios, A Special Report of Working Group III of the Intergovernmental Panel on Climate change. Nakićenović $\mathrm{N}$ and Swart R (eds). Cambridge University Press: Cambridge, UK and New York, USA 599 pp.

Intergovernmental Panel on Climate Change. 2007. Climate change 2007: the physical science basis. Contribution of Working Group I to the Fourth Assessment Report of the Intergovernmental Panel on Climate Change. Geneva, Switzerland.
Jones AR, Brunsell NA. 2009a. A scaling analysis of soil moisture-precipitation interactions in a regional climate model. Theoretical and Applied Climatology (in press). DOI:10.1007/s00704-0090109-x, in press.

Jones AR, Brunsell NA. 2009b. Energy balance partitioning and net radiation as controls on soil moisture-precipitation feedbacks. Earth Interactions 13: 1-25, DOI:10.1175/2009EI270.1.

Knapp AK, Briggs JM, Koelliker JK. 2001. Frequency and extent of water limitation to primary production in a mesic temperate grassland. Ecosystems 4: 19-28.

Knapp AK, Smith MD. 2001. Variation among biomes in temporal dynamics of aboveground primary production. Science 291: 481-484.

Köppen W. 1900. Versuch einer Klassification der Klimate vorzugsweise nach ihren Beziehungen zur Pflanzenwelt (Attempted climate classification in relation to plant distributions). Geographische Zeitschrift 6: 593-611-657-679.

Koster RD, Dirmeyer PA, Guo Z, Bonan G, Chan E, Cox P, Gordon CT, Kanae S, Kowalczyk E, Lawrence D, Liu P, Lu CH, Malyshev S, McAvaney B, Mitchell K, Mocko D, Oki T, Oleson K, Pitman A, Sud YC, Taylor CM, Verseghy D, Vasic R, Xue Y, Yamada T. 2004. Regions of strong coupling between soil moisture and precipitation. Science 305: 1138-1140.

Luo Y. 2007. Terrestrial carbon-cycle feedback to climate warming. Annual Review of Ecology and Evolutionary Systematics 38: 683-712.

Mahmood R, Hubbard KG, Carlson C. 2004. Modification of growingseason surface temperature records in the northern Great Plains due to land-use transformation: verification of modelling results and implication for global climate change. International Journal of Climatology 24: 311-327.

Marotz GA, Clark J, Henry J, Standfast R. 1975. Cloud fields over irrigated areas in southwestern Kansas - data and speculations. Professional Geographer 27: 457-461.

McCabe GJ, Palecki MA, Betancourt JL. 2004. Pacific and Atlantic Ocean influences on multidecadal drought frequency in the United States. Proceedings of the National Academy of Sciences of the USA 101: 4136-4141.

McMahon PB, Dennehy KF, Michel RL, Sophocleous MA, Ellett KM, Hurlbut DB. 2003. Water movement through thick unsaturated zones overlying the Central High Plains Aquifer, Southwestern Kansas, 2000-2001. USGS Water Resources Investigation Report 03-4171: 32.

Moore N, Rojstaczer S. 2001. Irrigation-induced rainfall and the Great Plains. Journal of Applied Meteorology 40: 1297-1309.

Nippert JB, Knapp AK, Briggs JM. 2006. Intra-annual rainfall variability and grassland productivity: can the past predict the future? Plant Ecology 184: 65-74.

Oke TR. 1982. The energetic basis of the urban heat island. Quarterly Journal of the Royal Meteorological Society 108: 1-24.

Olesen JE, Bindi M. 2002. Consequences of climate change for European agricultural productivity, land use and policy. European Journal of Agronomy 16: 239-262.

Palmer WC. 1965. Meteorological drought. Research Paper No. 45, U.S. Department of Commerce Weather Bureau, Washington, D.C.

Park S, Feddema JJ, Egbert SL. 2003. Impacts of hydrologic soil properties on drought detection with MODIS thermal data. Remote Sensing of Environment 89(1): 53-62.

Patterson J. 2008. An Analysis of Spring Bird Migration Phenology in Kansas. MA Thesis, Kansas State University, Manhattan, Kansas.

Peterson TC, Vose R, Schmoyer R, Razuvaev V. 1998. Global Historical Climatology Network (GHCN) quality control of monthly temperature data. International Journal of Climatology 18: $1169-1179$.

Peterson TC, Vose RS. 1997. An overview of the Global Historical Climatology Network temperature database. Bulletin of the American Meteorological Society 78: 2837-2849.

Pielke R, Nielsen-Gammon J, Davey C, Angel J, Bliss O, Doesken N, Cai M, Fall S, Niyogi D, Gallo K, Hale R, Hubbard KG, Lin XM, Li H, Raman S. 2007. Documentation of uncertainties and biases associated with surface temperature measurement sites for climate change assessment. Bulletin of the American Meteorological Society 88: 913-928.

Pielke RA, Stohlgren T, Schell L, Parton W, Doesken N, Redmond K, Moeny J, McKee T, Kittel TGF. 2002. Problems in evaluating regional and local trends in temperature: an example from eastern Colorado, USA. International Journal of Climatology 22: 421-434. 
Robeson SM. 2004. Trends in time-varying percentiles of daily minimum and maximum temperature over North America. Geophysical Research Letters 31: L04203.

Rozoff CM, Cotton WR, Adegoke JO. 2003. Simulation of St. Louis, Missouri, land use impacts on thunderstorms. Journal of Applied Meteorology 42: 716-738.

Sacks WJ, Schimel DS, Monson RK. 2007. Coupling between carbon cycling and climate in a high-elevation subalpine forest: a model-data fusion analysis. Oecologia 151: 54-68.

Samson F, Knopf F. 1994. Prairie conservation in North America BioScience 44: 418-421.

Scanlon BR, Reedy RC, Stonestrom DA, Prudic DE, Dennehy KF. 2005. Impact of land use and land cover change on groundwater recharge and quality in the southwestern US. Global Change Biology 11: $1577-1593$.

Segal M, Pan Z, Turner RW, Takle ES. 1998. On the potential impact of irrigated areas in North America on summer rainfall caused by large-scale systems. Journal of Applied Meteorology 37: 325-331.

Skaggs RH. 1978. Climatic change and persistence in western Kansas. Annals of the Association of American Geographers 68: 73-80.

Stahle DW, Cook ER, Villanueva Díaz J, Fye FK, Burnette DJ, Griff RD, Acuña Soto RR, Seager R, Heim RR Jr. 2009. Early 21stcentury drought in Mexico. EOS Transactions 90(11): 89-90.
Tebaldi C, Knutti R. 2007. The use of the multi-model ensemble in probabilistic climate projections. Philosophical Transactions of the Royal Society 365: 2053-2075.

Thornthwaite CW. 1943. Problems in the classification of climates. Geographical Review 33(2): 233-255.

Thornthwaite CW. 1948. An approach toward a rational classification of climate. Geographical Review 38(1): 55-94.

Trewartha GT, Horn LH. 1980. An Introduction to Climate, 5th edn. McGraw-Hill: New York.

US Global Change Research Program, National Assessment Synthesis Team. 2001. The Potential Consequences of Climate Variability and Change. Cambridge University Press: Cambridge.

Venkatatamana S, Loope DB, Swinehart JB, Mason JA, Oglesby RJ, Rowe CR. 2006. Large wind shift on the great plains during the medieval warm period. Science 313: 345-347.

Volk M, Niklaus PA, Korner C. 2000. Soil moisture effects determine $\mathrm{CO}_{2}$ responses of grassland species. Oecologia 125: 380-388.

Woodhouse CA, Overpeck JT. 1998. 2000 years of drought variability in the Central United States. Bulletin of the American Meteorological Society 79(12): 2693-2714.

White MA, Nemani RR, Thornton PE, Running SW. 2002. Satellite evidence of phenological differences between urbanized and rural areas of the eastern United States deciduous broadleaf forests. Ecosystems 5: 260-277. 